\title{
THE WORK EFFICIENCY MANAGEMENT (AS A) - DETERMINANT OF THE DEVELOPMENT OF MODERN ORGANIZATIONS
}

\begin{abstract}
Today's enterprises, regardless of their size, have to face many new challenges. These include globalization, the use of new technologies and the creation of intellectual capital as a source of the competitive advantage. And moreover the need to act in a changing environment.

The organizations must be characterized by a speed of action, flexibility and the ability to learn quickly. They should have employees with high competences who can effectively manage work. The work efficiency management is a business management subsystem. The implementation of this system should take into account not only the material potential, but above all the people. It has a decisive impact on the company's competitiveness in the market. It allows you to achieve a success. Lawyers are a flexible and dynamic resource that is able to quickly respond to any changes in the company's strategic goals. Currently, the human resources in the organization are treated as the most precious and the most expensive way. The idea of managing work efficiency is to strive to make the best use of human resources by constantly shaping the engagement and inspiration of people for effective actions for the benefit of the enterprise. A comprehensive approach to work efficiency management is an invaluable tool in building a competitive advantage.
\end{abstract}

Keywords: work efficiency, competencies, coaching, strategy, efficiency management

\section{INTRODUCTION}

The existence and development of the company is conditioned by the efficiency and purposefulness of implementing all the functions of the organization management. One of them is a personal function understood 
as tasks and duties that the company should implement for its own staff. These activities determine the possibility of the organization's requirements for its employees. (A.Szałkowski, 2006, p. 21). They refer to the changes in the personnel function itself, the changes in the approach to staff as well as the changes in relations between the personnel function and other functions of the enterprise. The tendency of these changes can be formulated as the integration of management process. It concerns the employees themselves and their cooperation with the company as well as their integration with the environment. The basics of modern human resources management are determined by the following factors (M. Armstrong, 2005, p. 29):

1) mutual expectations of employees and employing their organizations

2) concluding numerous contracts describing the mutual expectations of the organizations and the employees

3) creating the conditions that ensure mutual expectations

These factors complement each other and shape work relations in the organization. It needs to be emphasized that the basis for human resource management is the recognition of employees as a valuable and invaluable resource for the organization.

\section{Organizations IN THE FACE OF CHANGES}

The enterprises which want to succeed in a changing environment are those that successfully implemented good change programs (E. MasłykMusiał, 2003, pp. 138-139). These programs have become a lifestyle for them and have special features, such as:

- They are flexible

- Their structures are flat

- They notice changes quickly

- They build their image having the shareholders in mind

- They create conditions for employee's involvement and a sense of responsibility for the tasks being carried out

- They reward creative and enterprising people

- They learn and are able to make accurate choices, using management practices which help them succeed in business 
Contemporary organizations are based on team work. They are more connected with customers and suppliers. They are quality-oriented and with global orientation and activity (P. Płoszajski, 2001, p. 14). In the opinion of Z. Sekuła, in order to function properly in the future, the organizations must choose the right strategy in the field of production. And, they should also have employees with appropriate competences. Those organizations are able to work flexible and have the intuition in predicting future changes and ability for quick adaptation to them (Z. Sekuła, 2002, p. 35).

The changes in the scope of work and therefore among people who carry it out, are the manifestation of a changing enterprise. Those changes are about (Z. Sekuła, 2002, p. 246):

- Decreasing the scope of work

- Work division

- Changes in the relationship between the employer and the employee

- Increase the meaning of the concept of work

- Demand for knowledge

Today's organizations need knowledge capital. The care for the growth of intellectual capital (M. Gableta, 2003, pp. 135-136) becomes the main task of the changing enterprise. According to W. Grudzewski and J. Hejduk, the contemporary organizations should be entrepreneurial. They should be capable of utilizing the achievements of science, techniques and technology as well as using the modern management systems for investing in such conditions that allow to occupy a certain position in the market by acquiring clients and achieving satisfactory results in competitiveness (W. Grudzewski, J. Hejduk, 2004, p. 26) .Furthermore, the above-mentioned authors direct our attention to knowledge that has become a company's resource (W. Grudzewski, J. Hejduk, 2004, p. 135). A knowledge-based organization is an organization whose structure is subordinate and aimed at creating added value based on the effective use of knowledge. Those organizations have the following characteristics (W. Grudzewski, J. Hejduk, 2004, p. 135):

- They produce goods rich in knowledge.

- They employ high-class specialists

- Their market value is decisively determined by their value of intellectual capital 
The organization is an open system that operates in the environment which provides its resources to the organization and expects from it products or effects beneficial for the environment. The organization is consisted of subsystems, such as the management subsystem that is responsible for managing the entire structure. The management may be defined as a coordinated organizational action to achieve the goal and to give the possibility of its survival. One of the forms of such action is a strategy which means the possibility of making choices. The constructing a good strategy consists in accurately analyzing the environment. It allows to consciously managing the goals of the organization. The organizations pursue the social structure goals and bring order. In the sphere of culture, however, they satisfy the social needs. The most important tasks of the organization concern the management of work efficiency, which allows achieving success in a competitive market.

\section{THE GENESIS OF THE CONCEPT OF WORK EFFICIENCY MANAGEMENT}

The management through effects is a key issue of management science. It applies to traditional management through goals, which has been improved by new solutions. Currently, the management by effects refers to the performance of management techniques by result. Its purpose is to create the areas of responsibility, to increase the freedom of action for both the managerial staff and employees and also to promotion and to develop the management with entrepreneurial features. It should be emphasized that the management through effects is the result of the causes of the organization's environment, company's strategy, organizational structure and culture. (A. Pocztowski, 2008, p. 251) The management through effects is a formalized and integrated process, shaping the characteristics, behaviours and results of human activities related to the performed work. Its overall purpose is to create and to provide value to recipients. Such concepts as cooperation and understanding, not control, clear definition of the areas of effectiveness and goals of the company and, in addition, continuous improvement in this field are seen as the base for the philosophy of managing people. The most important seems to be the system of planning the effects of all employees and the compliance with ethical principles that result in respect for employees. 
Therefore, the effects management system should include the following components (R.S. Williams, 2000, p. 9):

- The management of efficiency of the entire organization

- The employee efficiency management

- The integration of efficiency management at individual levels

\section{Management process through effects at the level of the entire organization}

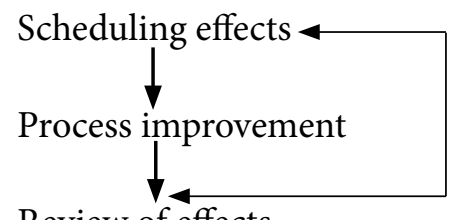

Review of effects (vision, strategy, goals, factors)

(TQM Reengineering, building opinions)

(measurement, assessment, audit)

\section{Measurement of management through effects at the employee level}

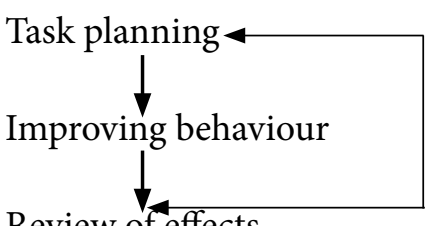

Review of effects
(Setting tasks in the adopted efficiency areas)

(Monitoring and supporting behaviours)

(measurement and feedback)

Source: own study based on A. Pocztowski 2008 p. 253

The basis for the management process through effects at the employee level is primarily the planning and setting of tasks in the adopted areas of effectiveness. Then, the improvement of behaviours by monitoring and supporting them must be done. The last important stage is the review of effects based on measurement and reliable feedback on the contribution of individual employees to process of achieving the organization's goals. The consequences of such actions are personnel decisions related to remuneration, the need for training as well as the possibility of transferring an employee to another position. When creating a work efficiency management strategy, it is helpful to find answers to the following questions: 
1. What are the organization's expectations regarding work efficiency?

2. How should human recourse management be managed in order to use their full potential?

3. How should the senior management staff be organized?

4. How can the management through effects correspond with other company activities supporting talent management?

5. Does the approach to managing the effects of work match the organizational culture of the company?

Many modern organizations experience a number of factors related to human management. It is the effect of hiring employees of a new organization expecting from employers a wide training package and a transparent career path. The visible recruitment of employees from the "Y" generation forces the employer to reorganize the approach to the problem of managing work efficiency. An increasingly common phenomenon is the transition from employee evaluation based on their rivalry to the use of coaching and other methods of employee development in order to increase work efficiency. The conducted research in Poland has shown that companies investing in coaching and training receive a greater degree of employee engagement and their effectiveness. (A. Szejniuk, 2015, p. 76). The task of coaching is the mutual support of employees, which results in general staff development, elimination of excessive costs as well as in creating a coaching culture.

The efficiency management is a key system for the organization supporting the implementation of its business strategy. The system of periodic evaluations or the model of management by objectives (goals) is an effective method of improving efficiency and quality of work.

The employees' goals should be correlated with the company's goals. The efficiency management is characterized by repeatable management processes such as (M. Kostera, 2000, p. 75):

- defining the business processes,

- determination of measures on many levels

- receiving the information (measurement of effectiveness)

- operation (adaptation and change of business)

- reaction (re-assessment and redefinition of the business goals) 
- operation (reassessment and redefinition of efficiency measures)

- achieving the business goals

Source: Bersin \&Assodates Research: Mig-Impact Performance Management was made in 2011 among the group of $500 \mathrm{HR}$ managers

As part of work efficiency management, an important task is to measure the achieved work results. It results from the delivering the information regarding the analysis and assessment of the effects achieved in the past. On this basis, it allows you to undertake improvement activities in the future. Thus, the measurement is important at the planning stage as well as the work evaluation stage. The complexity of measurements results from creating the appropriate systems for measuring the effects, which concerns the organizational level and the employee's level. The condition for correct formulation and implementation of the management system by effects is its proper development. An important role in this process is played by the communication system in the organization. It should be primarily concrete and its goals should be clear and understandable. In addition, it should be measurable by a quantitative and qualitative form that can be verified. It is also important to take into account organizational conditions and the possibilities of employees. Thus, the matching employees' effectiveness with the organization's goals must be done. The area that needs to be analyzed is the analysis of effects, which includes assessment, measurement and feedback. It concerns the following issues (M. Armstrong, 2005, p. 45):

- the measurement of the effects achieved in relation to the adopted assumptions and standards

- providing employees with feedback on their effectiveness

- positive reinforcement by expressing appreciation for achievements

- the exchange of views on previous achievements and future actions aimed at improving work efficiency

- the agreeing on the action plan and determining the support which may be given by the managers.

The organization of managers' meetings with employees should take into account the achieved results. They should refer not only to the adopted plan but 
also to the behaviours by which the intended results were achieved. Therefore, those types of questions should be asked. (A. Pocztowski, 2008, s 263): 1. Is there a gap between planned and achieved effects?

2. What factors make it difficult to achieve the desired results?

They questions and answers allow avoiding and duplicating of possible mistakes while evaluating work efficiency. At the organizational level, the measurement system should cover the following areas of the measurement range (R.S. Williams, 2000, p. 66):

- contribution to achieving goals

- quality

- quantity

- productivity

- satisfaction of internal and external clients

The problem of work efficiency is identified with personal control, increasing the value of human capital. (A. Szejniuk, 2015, pp. 42-43).

The personal controlling can be used as an instrument of employment rationalization in the functional areas of the enterprise. Its aim is to increase efficiency by shaping the state and structure of employment as well as administering personal matters. It can be determined by various forms in individual enterprises that reflect the stages of its development. The features characterizing this development (Human Resources Management 2002/05 p. 21) are:

- single measures of employment, labour productivity, costs and time of work, and staff turnover

- meters selected to monitor strategic goals

- system of measures creating cause and effect relationships, partly connected with economic goals of the enterprise

- integrated with general controlling, a system for measuring the contribution of work effects to the success of the enterprise.

The measurement of work efficiency is possible thanks to a balanced scorecard (R.S. Kaplan, D.P. Norton, 2001, p. 42) which indicates the 
measurement of effectiveness taking into account shareholders, clients, improvement of internal business processes as well as learning and growth.

Measuring the effects of an individual employee concerns his or her results and behaviour in the work process. The bases of this measurement are reliably formulated goals and standards. The meters covering the area of results are related to the quality, the timeliness and the working time. On the other hand, the area of behaviour concerns the analysis and assessment of the work process, the way of performing entrusted tasks and the commitment and organization of own work. Measuring results and assessing behaviour is a complement to the analysis and evaluation of benefits in the area of personal development through the research on the competence and satisfaction of employees during the performed work.

The efficiency management is a key system for the organization supporting the implementation of its business strategy. An effective method of improving efficiency and quality of work is the system of periodic evaluations or the model of management by objectives (by goals).

The employees' goals should be correlated with the company's goals. The efficiency management is characterized by repeatable management processes such as (A. Pocztowski, 2008, p. 143):

- defining the business processes,

- determination of measures on many levels

- receiving the information (measurement of effectiveness)

- operation (adaptation and change of business)

- reaction (re-assessment and redefinition of the business goals)

- (reassessment and redefinition of efficiency measures)

- achieving the business goals

Work efficiency management ensures:

1) the analysis of the existing system in terms of its business functionality - proposing necessary changes

2) the selection of the optimal efficiency management model for the company

3) the development of assumptions for the entire process and necessary tools the development of a procedure defining all formal issues related to the

4) implementation and functioning of the system 
5) the preparation of the implementation and communication plan

6) the conducting training of employees and managers in the field of goal monitoring and conducting evaluation interviews

7) the linking of the results of evaluations to the training system, remuneration, promotions and development

There are the benefits of implementing an efficiency management:

1. The concentration of employees' activities on achieving key and priority goals of the company.

2. The Increase of work efficiency and focusing on the results.

3. The minimization of threats thanks to constant monitoring of results and ongoing analysis of activities.

4. The optimization of management costs.

5. The increase employee awareness of their role in the company and responsibility for the result.

6. Regular feedback on the quality of work and presented attitudes.

7. Correct communication on the employee-supervisor line.

8. The increase of employee motivation due to a real link between the results of work and the remuneration system.

9. More effective training and development programs constructed on the basis of diagnosed competency gaps.

10. Selecting and supporting the most valuable employees for the company.

11. Better identification of employees with the company, its organizational culture, obligations of standards and values.

12. Strengthening the right attitudes and desirable behaviours of employees.

\section{MANAgEMENT BY EFFECTS}

Among the activities that make up the personnel function in the organization, the effects management system is of great importance. The factors that are particularly important in the process of implementing management systems through effects include (A. Pocztowski, 2008, p. 269):

- the economic factors

- the technological innovations

- the organizational changes 
- the organizational culture model of the work relations

- the theories and trends in the sciences of management

The globalization of the world's economy and the economic situation are elements of economic factors aimed at increasing the efficiency of the organization. It requires continuous improvement of quality and lowering costs. It also requires shortening the implementation time of assigned tasks. The mentioned factors are subject to continuous improvement. The technological innovations are other factors determining the management through effects. Undoubtedly, they stimulate the increase of efficiency at all levels of the organizational structure. Such action allows the organization to achieve a competitive advantage on the market and it affects the organization and way of managers' work (A. Szejniuk, 2016, p. 93).

The task of an ethical manager is to use methods and management techniques that can increase efficiency. An important role in creating value for the organization is played by knowledge workers who can and who want to learn (A. Szejniuk, 2016, p. 193). The adaptive abilities to changes taking place in the environment are determined by the special roles of learning processes. The principles and forms of work change, having an impact on activities undertaken as part of management by objectives (goals). The technological changes have a significant influence on interpersonal relations between employees as well as between management and employees being entities of the management through effects. The organizational changes are equally important factor affecting the way of implementation the process of management by effects. They are related to the restructuring process and, in addition, they are related to the roles performed by employees and senior staff.

The reporting and evaluation processes based on organizational structures are important in the organization. It should be underline that the importance of managerial competences increases. They allow to organize the work better and to achieve the goals faster. The most important factor affecting the functioning of the management system through effects is the organizational culture. It is important for creating values and standards in determining efficiency standards. It gives patterns of employee involvement 
in the functioning of the organization. It allows determining the relationship between the management and employees regarding the setting of goals and, above all, their evaluation. It creates a formal model of work relations, which determines the implementation and the functioning of the rules of this system. The development and implementation of the management process by effects as tools requires (A. Pocztowski, 2008, p. 271):

- ensuring vertical integration between organizational and individual effectiveness.

- the consistency between goal setting, its measurement, analysis and evaluation

- ensuring horizontal integration between management through effects and other elements of the personnel function, especially the remuneration and the development of employees

- adjustment of detailed solutions in the procedure of activities to the specifics of organizational culture

- the involvement of all entities of the human resources management process in the implementation of the project

- the effective communication that contributes to understanding the nature of management through effects, its acceptance and commitment to the process

- a proactive and future-oriented approach and treatment of management through effects as a continually repeated and improved process.

It should be stated that management through effects is a fundamental issue in the human resources management system. In the area of the personnel function, it is of strategic importance.

\section{FEATURES OF THE EFFECTIVENESS OF PERSONNEL MANAGEMENT IN THE ORGANIZATION}

The improvement of human resources components has always been of interest in both theory and practice. There has been a change in the understanding of training to the overall development of human potential which is the basis of human resources management. They concern various aspects covering the knowledge, skills and abilities of people performing work 
(A. Pocztowski, 2008, pp. 277). Human resources development is a deliberate configuration of projects of enriching knowledge, developing capacities and shaping values that lead to an increase in its effectiveness and to increase the market value of the human resources. Human resources in organizations are the greatest value and source of success in a competitive market. Investing in the development of human resources depends on the culture of the organization and, therefore, it depends from the needs of the organization. One of the key functions of the company is the personnel function that determines the organization management process. The importance of the personnel function in a modern enterprise is determined by the following factors (M. Kostera, 2000, pp. 24-25):

- high labour costs,

- the significant influence exerted by the personnel function on the shaping of trends in productivity, which largely determines the competitive position of the company,

- the ability of social potential to create innovations,

- particular sensitivity of social potential to incorrect treatment,

- the personal function in the way of modelling organizational culture in the direction of efficiency.

The human resource department in the organization is responsible for introducing management instruments in the company. It should develop economic solutions in the area of human resources. Its tasks include: the legal services, the planning of employment and career of future and current staff. The analysis of the work efficiency of individual employees takes place as part of the work efficiency management process. The purpose of this action is to achieve a competitive advantage on the market. It is possible through the implementation of set goals and continuous improvement of the organization staff's skills. The following resources are the basis of work efficiency management (M.Armstrong, 2005, p. 200):

- creating a management process that will support the implementation of the company's economic strategy,

- developing and maintaining a process which will enable all employees to fulfil their responsibilities within the organization, 
- enabling employees to independently control their own activities,

- partnership relations between workers and management staff,

- setting the objective as the basis for the performance and development criterion,

- emphasizing the role of evaluation and appreciating the achievements of employees,

- maintaining a fair system of assessment and appropriate rewarding of personnel

- recognition of work efficiency management as an integral element of management.

The intended result is achievable when the managers responsible for human resources management prepare tools to improve work efficiency. The employers recognize the importance of employees' competences. It turns out that the competence management plays a significant role in the process of human management in the organization. They seek the new methods and the new ways to maximize the use of knowledge, skills and social competences. Therefore, the identification and the development of competences is an important task that will enable the organization to function most effectively. The introduction of competence models plays an important role in human resources management. The goal, in this case, is to increase the competence and flexibility of employees. Increasing the competences allows the employees to double the number of tasks performed and it is related to their work efficiency.

In the organization, the managerial staff should make decisions related to the direction of competence development for individual employees. First of all, it is about those competences which are difficult to replace and their value is crucial for the organization. The development of competencies is conditioned by the possibility of determining the exact manner of implementation. The motivational factor is extremely important. Without this factor, the development is impossible. The sources of professional development mainly concern: the experience gained at the workplace and, in addition, the information and tips obtained from colleagues as well as the trainings which create the possibility of not only broadening the scope of competence but also organizing the knowledge that employees already have. 


\section{FACTORS INFLUENCING MANAGEMENT BY EFFECTS}

Work efficiency means a value that changes over time. It depends on the action of many factors. They should be identified and analyzed in order to optimize the level of work efficiency. T. Gilbert has developed a model that facilitates the identification of factors affecting efficiency in six areas (Gilbert, 2004):

1. Resources - considered as work tools

2. Business processes

3. Information

4. Specialist knowledge

5. Motivation / commitment

6. Quality of life and health aspects related to work in the organization

The above-mentioned first three areas are related primarily to the organization itself and its impact on the work of individual people. Other areas res related directly to employees performing assigned tasks. In order to increase efficiency, the various conditions should be taken into the consideration so the employee can demonstrate an appropriate level of efficiency in his or her work. For the organization, the key is to match the employee's potential to his or her functions using the definition of the real potential. Also, it is important to determinate employee's development plan by indicating development activities and the factors which should be performed. In addition, building commitment and continuous development of resources by finding weaknesses and strengths of their activities must be done.

The competency model allows employees to develop a vision of their career in an enterprise. The levels of development of individual competencies are interrelated in a way that shows the competence requirements for individual positions in the organization hierarchy. The idea of employee development in the company is promoted by the human resource department. Its activity is to support and to direct employees through the development of their individual development plans. The selection of development tasks is related to the competences put in place in a given position in the organizational structure of the enterprise.Employeesupport toolsused in thecompanyare: coaching, mentoring, development workshops as well as meetings with a development advisor. 
Of course, the degree of implementation is verified after a specified period of time. The competency model indirectly affects the amount of employees' remuneration. The principles of remuneration and the amount of the increases are communicated in a standardized manner by the organization. The communication in this area should also be transmitted on an ongoing basis during meetings with superiors. Regardless of the assessment, development and remuneration process, the competency model can be used in the recruitment process. It is a permanent reference point at all stages of the recruitment process.

The asset of the discussed process is the inclusion of employee development in the company's core competencies. By promoting such behaviour, the organization contributes to the promotion of attitude of lifelong learning. The company's task is to support the development of employees in their careers. Among the activities promoting lifelong learning, the attention should be paid to initiatives implemented as part of corporate social responsibility. Therefore, it maybe be done by promoting the company among universities and at job fairs. These activities allow acquiring the best candidates for new positions in the organization.

\section{ASPECTS OF MANAGEMENT THROUGH EFFECTS}

An important aspect in the management through effects is the selection of employees for the team responsible for the implementation of specific tasks. The team's effectiveness is determined by the following features (M. Tyreńska, 2009, p. 257):

- having a common goal,

- working out a way accepted by everyone,

- members have complementary skills,

- each member works for the team and he or she is responsible to team,

- everyone is involved and responsible for what they do.

Therefore, it is necessary to establish cooperation rules. Their observance limits conflicts and, above all, it will improve intra-group processes. The selection of team members is determined by the competency model. It allows acquiring people who have the required competences to 
perform the set tasks. These, in turn, define the organization of teamwork, plan activities to be carried out and their review. To achieve the results, an incentive program for the entire team is necessary. The supervisor should know the needs of his or her employees, which may be used when assigning tasks. The managerial staff should motivate their subordinates to fulfil their duties with commitment. This action will contribute to the increase of productivity and work efficiency.

The motivation should be an inspiration to satisfy the social and psychological needs of all employees. It is worth emphasizing that every person has different needs. There are internal needs that result in achieving goals at work and in the professional environment. The external environment also has a big impact on employees and on the actions which are taken in the organization. The prizes, bonuses and recognition remain important too. It is important to ensure that external and internal factors are interrelated. Another important factor in the motivation is give to the employee systematic feedback about the effects of his or her work. Its lack has negative consequences for current and future work.

Information about the effects of work should be and, above all, consistent with the employee's feelings. Skilful use of feedback is of the great importance when the tasks are entrusted to people or subgroups. The feedback is a safe and effective way of indicating the extent to which objectives have been achieved and, above all, where the work needs to be improved. The working conditions are also the important factor affecting the efficiency of employees.

They play an important role in any organization regardless of its size or location. Their level determines the employee's sense of satisfaction. The organizations which care for work efficiency must ensure the best working conditions for employees. In addition, they should be well motivated and involved. The working conditions are important in shaping employee performance. The better they are, the more productive the workers are, which translates into the results and therefore into the market position of the company. 


\section{SUMMARY}

Work on efficiency should be done at every stage of human resource management - starting from the analysis of work, recruitment and selection through the training, employee evaluation and ending with the organization of working conditions. The effective work of people results from a number of determinants among the most important is the pro-effective organizational culture and the related incentive system.

The implementation of an effective human resources management system is achieved thanks to motivated staff, their involvement in the organization's objectives and appropriate motivation. To effectively manage personnel, the organization should constantly improve the motivating system, adapting it to the current needs. The implementation of an effective management policy through effects based on the development of employees' competences creates the opportunity to gain an effective team. Thanks to the stability of the company and the way in which the people are treated, the organization is successful in a competitive market.

\section{Bibliography}

Armstrong, M. (2005). Zarządzanie zasobami ludzkimi, Kraków: Oficyna Ekonomiczna. Oddział Polskich Wydawnictw Profesjonalnych. ISBN 8389355884.

Gableta,M \{ 2003 \},Człowiek I praca w zmieniającym się przedsiębiorstwie.Wyd. AE,Wrocław

Gilbert, T.F (2004). Human Competence International Society for Performance Improvement, New York: Silver Spring. ISBN 978087996154.

Grudzewski, W., Hejduk, J. (2004). Przedsiębiorstwo przyszłości, Warszawa: Wyd. Diffin. ISBN 8372510830.

Kaplan, R.S., Norton, D.P. (2001). Strategiczna karta wyników. Jak przełożyć strategię na działania, Warszawa Wyd. PWN. ISBN 8301133856.

Kostera, M. (2000). Zarządzanie personelem, Warszawa: Wyd. PWE. ISBN 8320811937.

Masłyk-Musiał, E. (2003). Strategiczne zarzadzanie zasobami ludzkimi, Warszawa: Oficyna Wydawnicza Politechniki Warszawskiej. ISBN 8372071918.

Płoszajski, P. (2001). Organizacje przyszłości: wirtualny splot kontraktów. W: Grudzewski W.M., Hejduk J.K. (red.), Przedsiębiorstwo przyszłości, Warszawa: Wyd. Difin. ISBN 8372510830. 
Pocztowski, A. (2008). Zarządzanie zasobami ludzkimi, Warszawa: Wyd. Polskie Wydawnictwo Ekonomiczne. ISBN 8320816629.

Sekuła, Z. (2002). Controlling personalny, cz. II: Strategie personalne zadania i narzedzia controllingu personalnego, Bydgoszcz: TNOiK. ISBN 8387636738.

Szałkowski, A. (2006). Podstawy zarządzania personelem. Kraków: Wydawnictwo Akademii Ekonomicznej. ISBN 8372523150.

Szejniuk, A. (2015). Coaching - narzędzie rozwoju kompetencji zawodowych, „Journal of Modern Science", Vol. 3/26/ 2015. ISSN 1734-2031.

Szejniuk, A. (2015a). Controlling personalny w procesie zarzadzania zasobami ludzkimi, „Journal of Modern Science”, Vol. 2/25/ 2015 Józefów. ISSN 1734-2031.

Szejniuk, A. (2016). Etyka menadżerska w zarzadzaniu zasobami ludzkimi, „Journal of Modern Science” Vol 1/28/ 2016 Józefów. ISSN 1734-2031.

Szejniuk, A. (2016a). Wiedza - podstawa funkcjonowania organizacji w kontekście dobrych praktyk.,Journal of Modern Science Vol 4/31/2016 Józefów,ISSN 1734- 2031

Such-Pyrgiel, M. (2018). Nowe modele biznesu $w$ dobie transformacji cyfrowej w: Społeczne ekonomiczne aspekty zarzadzania $w$ organizacjach przyszłości, M. Sitek, M. Such-Pyrgiel (red.), s. 39-56. ISBN 9788362753956

Tyreńska, M. (2009). Efektywność zarzadzania zasobami ludzkimi w aspekcie terminologicznym i metodologicznym. Zeszyty Naukowe Małopolskiej Wyższej Szkole Ekonomicznej w Tarnowie 21/12/2009. ISSN 1506-2635.

Williams, R.S. (2000). Performance Management London: International Thomson Business Press. ISBN 1861521847. 
